\title{
Changing Shopping Spaces in Istanbul
}

\author{
Nilufer Saglar Onay* \\ ITU, Faculty of Architecture, Istanbul, Turkey \\ *Corresponding author: saglarni@itu.edu.tr
}

\begin{abstract}
In every culture commercial spaces and consumer goods communicate cultural meaning through social rituals. Shopping spaces in the Ottoman city were shaped by cultural aspects and they were developed spontaneously together with the changing dynamics of public life and activity. But, today the enormously productive world economy makes consumption a way of life and today's society in general seeks personal satisfaction in consumption. Products, marketing strategies, customer expectations and "spaces of exchange" change at an ever-increasing rate. Old commercial centres and spaces of exchange struggle to catch up with these changes while new shopping malls increase in number. This paper discusses the change in the meaning of shopping and shopping places by examining the historic commercial spaces and todays shopping environments in Istanbul.
\end{abstract}

Keywords: shopping spaces, commercial buildings, ottoman city

Cite This Article: Nilufer Saglar Onay, "Changing Shopping Spaces in Istanbul." World Journal of Social Sciences and Humanities, vol. 3, no. 3 (2017): 56-60. doi: 10.12691/wjssh-3-3-1.

\section{Introduction}

Commercial activity has always been one of the main components of public life. We can consider the relationship between architecture, commerce and identity in terms of everyday life, where the commodities we buy and the places in which we buy them are set within the context of popular culture. From the point of the view of cultural studies, consumption itself can be considered as a form of cultural production [1]. Until the industrial revolution, commercial activity was driven by the togetherness of production, exhibition and selling of goods. The typical Turkish bazaar could be a good example for the chain between the retailer, wholesaler, producer and artisan, and consumption worked as the generator of this chain system.

\section{Shopping Spaces of the Ottoman City}

The Ottoman city used to develop around a nucleus composed of a complex of buildings including the mosque, han, bath and bazaar. The relationship and position of these buildings were mostly determined by the main pedestrian flows in the city. Geist [2], described the Ottoman City as an infrastructure of inhabited alleys gradually flowing together towards the centre of collective life: a building complex consisting of a mosque, madrasa (school), bazaar (for retail trade), han (for wholesale trade, bath and other smaller institutions. In the example of Bursa, several hans were attached to the main street lined with shops on both sides. The bedesten and surrounding streets strengthened this commercial axe (Figure 1). The bazaar itself was located near the city walls on the side near to the main entrance of the city where the flow was more concentrated. Just like the Ottoman city, the bazaar did not come to being at once; it developed spontaneously in time according to the needs of the society.

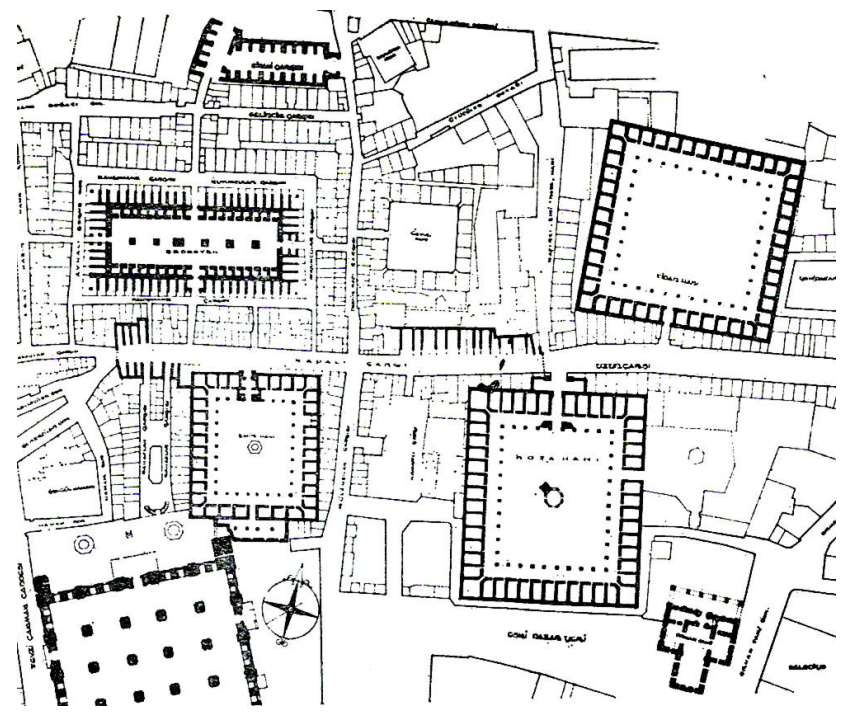

Figure 1. The Bursa Bazaar (Cezar, 1983)

In the Ottoman city an introvert life-style was developed. Frequented by people of all faiths and ages the bazaar was the only part of the city where this introversion was lessened. Although there were separate Moslem and non-Moslem quarters in the city, there was no such separation for the bazaar [3]. Therefore the bazaar was the most important public space of the city. It was not only for exchange but also for production. Most trade was in the hands of craftsmen. In small-scale shops, the craftsman was also the shopkeeper. Many of these craftsmen worked with young men called "çırak" and they used to teach all the ingenuities of the craft to the young. Thus the bazaar was also a place of education where all the arts and crafts 
were passed to younger generations. In the bazaar commerce was dominated by a set of unwritten ethic rules that generated a kind of public solidarity. The shopkeeper would send his second client to his neighbour if he had not sold anything yet [4]. In this sense the bazaar was not a commercial centre but it was the place for exchange for everything about human.

\subsection{Buildings of Commerce}

Most important commercial buildings that characterized the Ottoman city are the bedesten, covered bazaar, arasta and the han. But it is not always possible to define typologies or classify commercial buildings that characterize the typical Ottoman city. According to the special requirements of the city sometimes mix-use buildings were developed. Especially covered bazaars were developed as complex structures composed of streets lined with shops and they usually embraced other commercial buildings like bedestens, hans etc. According to Geist [2], an essential feature of all ottoman bazaars was the strict regularity of the interior and the spatial subdivision according to merchandise and artisan groups. In almost all commercial buildings shop was the smallest commercial unit. Bedestens and hans were invariably built of stones while arastas and covered bazaars could also be built with a variety of materials. The smallest unit in stone buildings was called "cell". The cells in a bedesten were usually identical in form and they used to face the central space covered with domes or cross vaults.

Commercial buildings differentiated from each other according to their roles in the city. Bedesten was like a bank and a stock market for the most valuable goods [5]. It was situated at the most valuable part of the bazaar and surrounded by important merchant groups. According to İnalcık [6], a city with bedesten was always open to international commerce. It was also the place where gold coins and jewelleries protected by the government were kept.

The arasta was developed as a part of a complex in order to meet its expenses. It differentiated from other commercial buildings with its linear configuration composed of a pedestrian axe lined with shops on both sides and it supported the flow between important structures of the city. While the bedesten stood as a single building which had a focal point, the bazaar and the arasta always created a flow of movement. The han and the caravanserai had similar architectural features and they both served as a roadside inn where travellers could rest and recover from the day's journey. The difference between them was their context. While the han was situated in the centre of the city for travellers like businessman and tradesman, the caravanserai was built on the trade routes like the silk way.

\subsection{The Development of the Bazaar of Istanbul}

Istanbul started to acquire the character of a Turkish city after the establishment of the two bedestens and the surrounding bazaar complex, both from the point of view of physical texture and social life. Like the typical Ottoman city, the bazaar of Istanbul was not planned at all, it was developed in time. The old Bedesten and surroundings were the first structures to be built. Later on Sandal Bedesteni was built. In time in the area between these two bedestens, new streets lined with shops began to develop and the whole area was devoted to commerce (Figure 2).

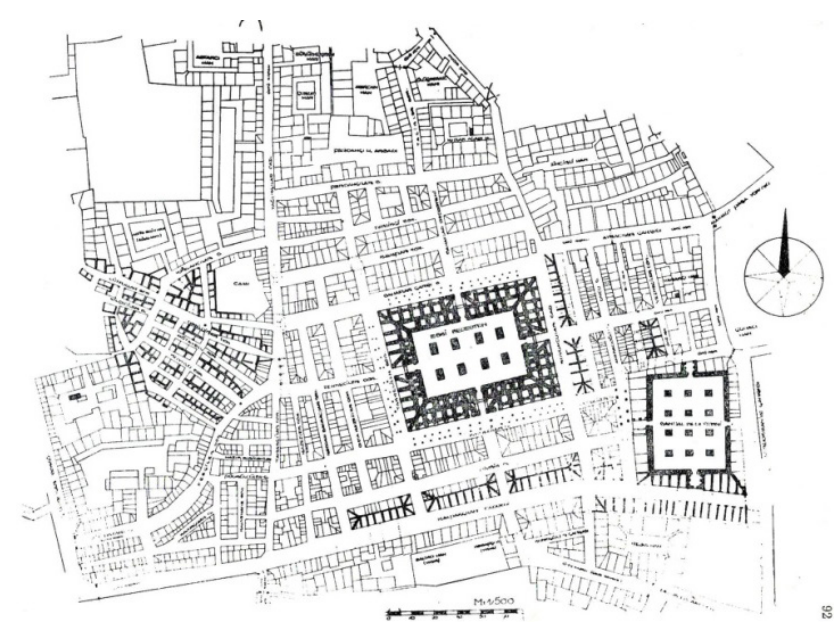

Figure 2. The plan of Grand Bazaar (Cezar, 1983)

The bazaar was composed of three main zones. The first zone, composed of the old bedesten and surrounding cells, was the core of the bazaar and it was especially used for storing the most valuable merchandise including the treasures of the state. Because of the need for security the walls were very thick with minimum openings very small in size. The second zone was the zone for the production, exposition and selling of the most valuable merchandise in the bazaar. Commercial units were bigger in order to embrace production and exposition areas. The third zone was some kind of peripheral zone less valuable and it was especially for everyday goods.

\subsection{The Bazaar as an Interior Environment}

The bazaar cannot be understood from outside, as it does not have continuous and well-defined facades. Borders of the bazaar were not strictly defined as it was always in a non-stop developing process. Today, because of the shops and structures attached to the outer walls, the only parts that can be perceived from outside are the gates of the bazaar. Therefore, the bazaar exposes and expresses itself with its interior environment (Figure 3). The interiors of the bazaar are dominated by arches of all kinds but the most spread arch type is the pointed Ottoman arch. The streets are also covered by barrel vaults with ribs of pointed arches. Every street has its own character as the height and width of the vaults vary according to the buildings and structures that surround them.

Typical shop in the bazaar had a kind of studio at the back where the craftsmen could work. On the face opening to the street there were wooden shutters, exhibition shelves and places to sit and rest. In front of some of the shops, there was an "eivan". During the Ottoman Period in the eivan the wooden extensions of the shop was organized. The eivan was partially separated from the pedestrian passage by wooden parapets or shelves in front. The role of the eivan was being an interface between the inner cell and the street and it was 
used for various activities like exhibition, sitting and bargaining (Figure 4). The display strategy was to display as much as possible on the facade because of the great variety and competition in the bazaar. The facade facing the street was usually full of shelves or hung materials. These objects helped to characterize the streets designated to different merchandise and artisan groups. The role of every single object was extended to become an important determinant of the interior atmosphere.

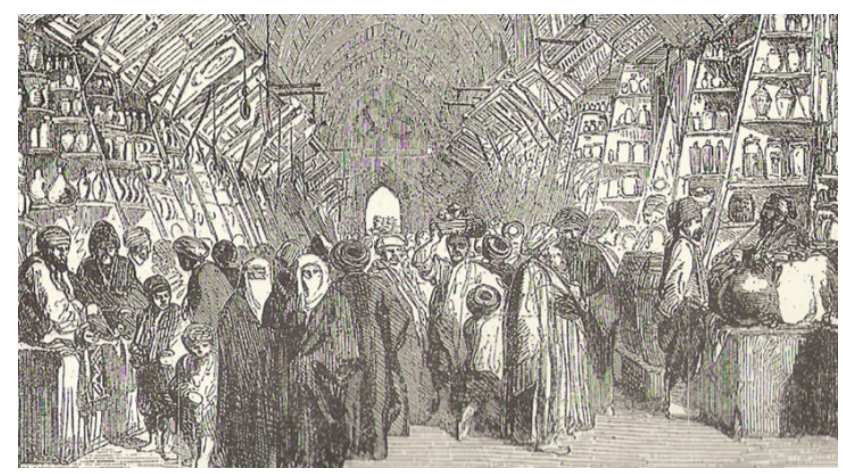

Figure 3. The bazaar as an interior environment [7]

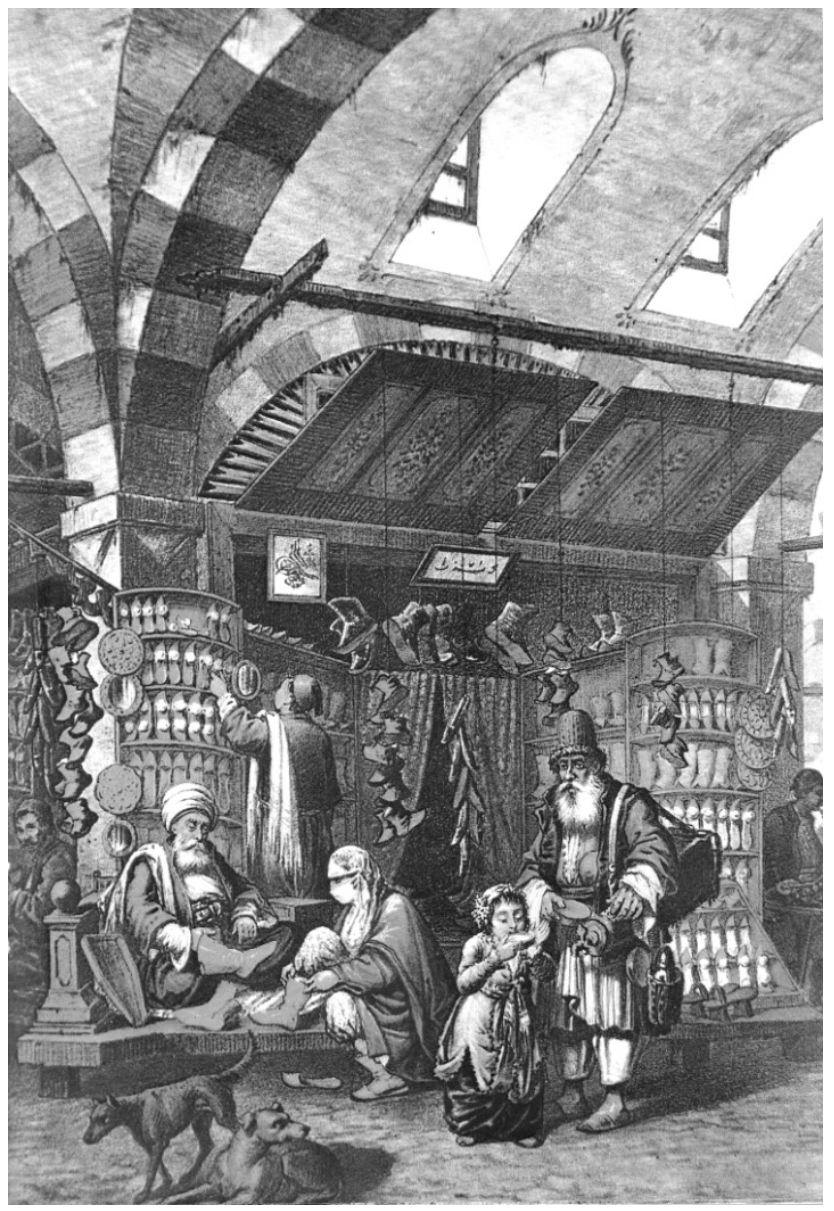

Figure 4. A typical shop in bazaar [7]

\section{Changing Shopping Spaces}

Until 1960 the bazaar was the core of commerce. It was the only commercial area where everything could be found. With the rapid increase in population sub centres began to be established and in these sub centres new commercial buildings were built. Turks as a society addicted to "what is new" began to prefer these new shopping areas. The new form of commercial space was the "shopping centre".

The bazaar lost its role as "being the only place where everything could be found" as the shopping centre offered the same thing. After losing a great part of local customers, the target consumer group became tourists. Many artisan shops were closed and they were replaced by souvenir shops with similar items. The increase in mass tourism In 1980's also decreased the quality of merchandise in the bazaar. In the beginning of 1990's the Gulf War, Turkey was defined as an insecure zone and American and Japanese tourists were taken away from the bazaar. The new dynamics of global economy and the introduction of Chinese and other Asian products damaged the 500 years old chain between the retailer, wholesaler and producer. Most parts of the grand bazaar were subject to intrusive interventions as a result of rapid and uncontrollable change.

In the last years, with the awareness of this loss and with the demand for high quality local goods, some enterprises are trying to bring back traditional shops and items back to the bazaar. In spite of all these changes and transformations in the last century, the bazaar did not really lose its particular role as the old commercial core. It is the most important tourist attraction of the city together with Sultanahmet and Santa Sophia. It is still the most important space of exchange for jewellery, rugs, traditional goods and antique items. There is still production at the back of many shops and hans. In the bazaar one can still find unique hand made products (Figure 5). So, it is still the commercial space where there is a great diversity of merchandise.

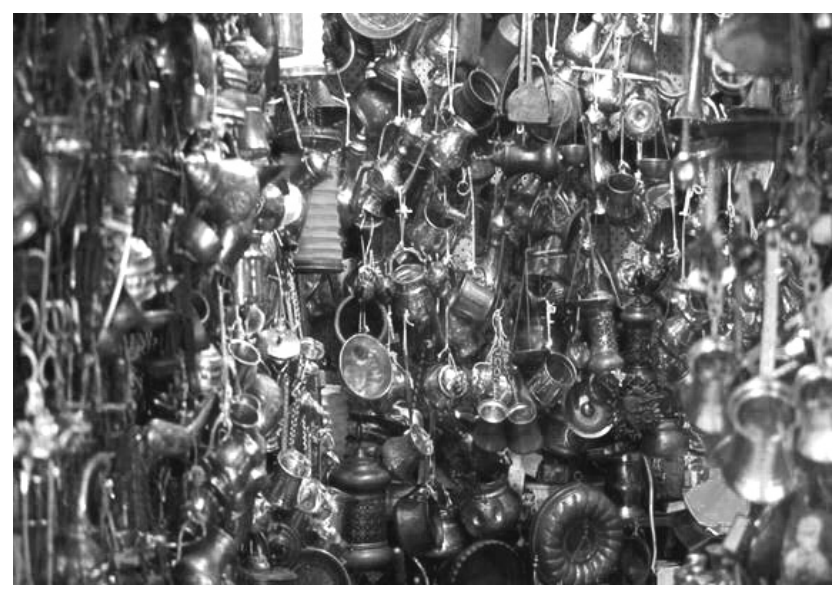

Figure 5. Unique hand made products in today's bazaar (author's photo)

Today's commercial system necessitates things consumed, burned up, worn out, replaced and discarded [8]. Shopping centres are the spatial complements of this system. In Turkey, first shopping centres began to be built as a result of changing demands and the entrance of new foreign products to the country after 1980's. The success of first examples like Galleria (1988), Atakule (1989) and Karum (1991) caused many others to be built in a very short time period. As a result of accelerating demand, the interest of the finance sector towards shopping centres increased and they started to be built by commercial doubts instead of architectural necessities [9]. As a result, 
the dominance of the finance sector brought a standard understanding of shopping centre design. Yirtic1 [10] argues that, the capitalist economy has seen space as a tool, which helped maximization of its profit; space has been reduced to an instrumental, quantitative value. So it is seen as if it can be destroyed if it is necessary, and brand new space can be created in which new relations and conditions occur.

Today, in every quarter of Istanbul, new shopping centres are introduced. Their number has reached to 114 and in the following 2 years 50 new shopping centres are expected to open. Most of the population passes their free time and weekends in shopping centres, which offer a wide range of goods, services and facilities. There is nothing wrong with the idea of having all kings of goods and services together. The development and purpose of the typical Turkish bazaar was similar to today's shopping malls. But the bazaar was developed according to the dynamics of social and commercial life with public contribution. On the other hand shopping malls as consumption generators are mostly designed to catch the eye, to be visually different just like the merchandise sold inside. Pallasma [11], argues that the detachment of construction from the realities of matter and craft turns architecture into a stage sets for the eye, devoid of the authenticity of material and tectonic logic. Commercial spaces that aim to create fascination in order to increase consumption are greatly abused by the "retina architecture" that stop the narrative flow of objects and damage contextual ties (Figure 6).

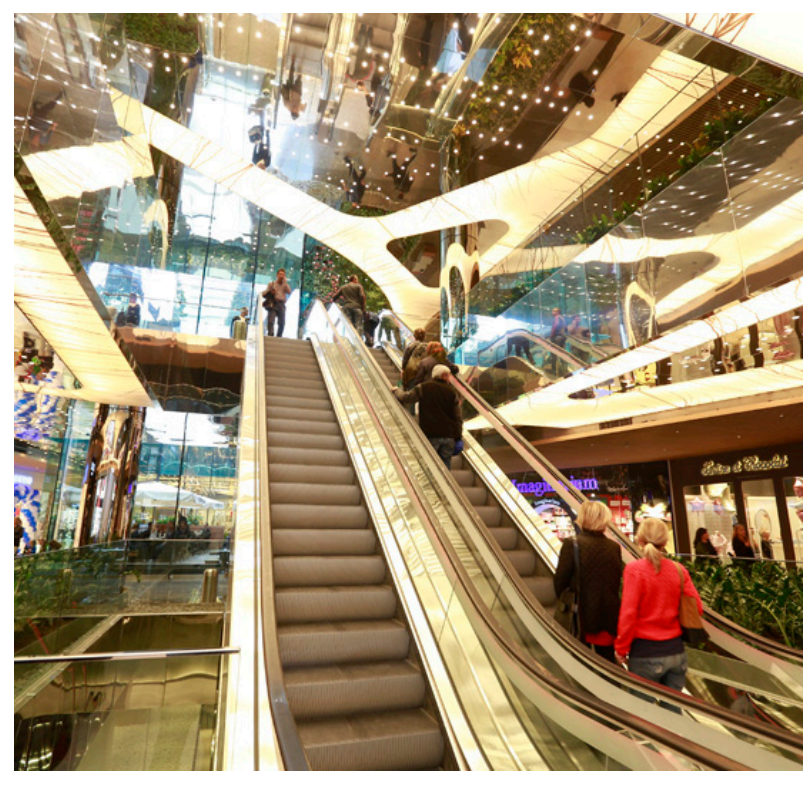

Figure 6. Interior of a recent shopping centre in Istanbul [12]

\section{Conclusion}

The bazaar of Istanbul has never been a static structure. It was always subject to change related to changing socio-economic factors. Like any other structure, it needs to change in order to survive. But if change is determined by the dominance of commercial profits without revealing the potentials of the existing environment, the bazaar can lose its particular role as being a commercial space of 550 years. According to [13], the Bazaar of Istanbul attracts people from all over the world because there shopping is still a ritual; there people exchange lives; there they try to give confidence to each other.

Today the old bedesten is perceived as an ordinary interior composed of narrow corridors lined with shops. Because of the dominance of shop windows and lighting elements, the original envelope with domes cannot be perceived at all. Most interiors in the bazaar are subject to intrusive interventions that hide the original envelope (Figure 7).

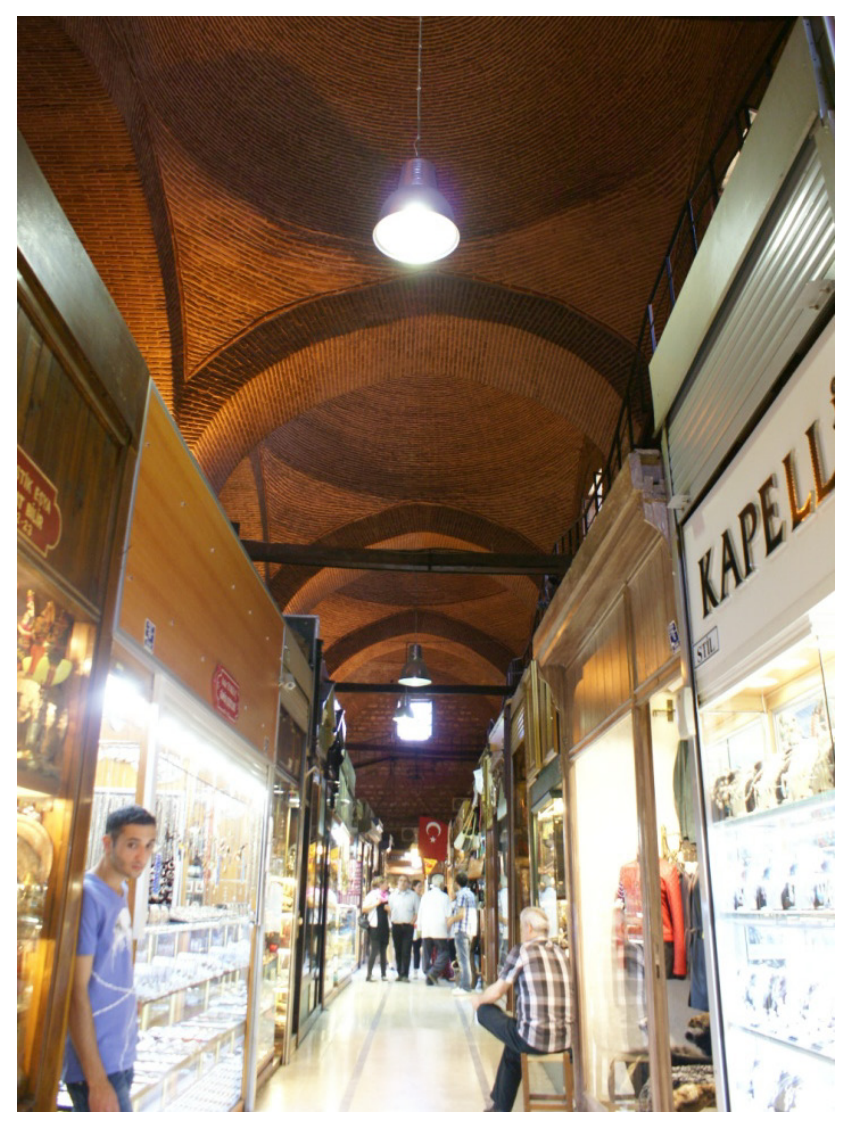

Figure 7. Interior of the Old Bedesten in Grand Bazaar [14]

Shopping is a global activity, but there is not necessarily a global solution. The new shopping malls mushrooming in the city may require designers to pump life and identity into the anonymous interior spaces. But old structures like the Grand Bazaar have their own spirits and potentials to be revealed. As consumer goods, display attitudes and marketing techniques change, spatial changes in the bazaar become almost inevitable. Even if we are dealing with a historic environment of 500 years we need solve all its problems in order to adapt it to new requirements so that the bazaar can survive. While touching an historic environment like the bazaar the most important concern needs to be the preservation of its public, social, economic, spatial and sensorial characteristics which all together define its cultural significance.

\section{References}

[1] Castle, H. (2000). Fashion+ Architecture, London: John Wiley\& Sons Ltd. 
[2] Geist, J. F. (1985). Arcades: The History of a Building Type, The MIT Press, London.

[3] Cezar, M. (1983). Typical Commercial Buildings of the Ottoman Classical Period and the Ottoman Construction Systems, Türkiye İş Bankası Cultural Publications, İstanbul

[4] Gülersoy, Ç. (1979). Kapalı Çarşının Romanı, İstanbul Kitaplığı Ltd. Yayınları, İstanbul.

[5] Mortan, K., Küçükerman, Ö. (2010) Çarş1, Pazar, Ticaret ve Kapalıçarşı1, Türkiye İş Bankası Kültür Yayınları, İstanbul.

[6] Inalcık, H. (2013). The Ottoman Empire The Classical Age: 13001600, Hachette, UK.

[7] Sevim, M., (2002). Turkey in Gravures, T.C. Kültür Bakanlığı Yayınları, Ankara.

[8] McCracken, G. 1990. "Culture and Consumption" Bloomington: Indiana University Press.
[9] Tokyay, V. (2005). Yeni Tasarım Kültürü Işı̆ğında Alışveriş Mimarlığı ve Gösteri Kültürü(1) , Yapı Dergisi, Eylül 2005, s58-64.

[10] Yırtıc1, H. -"The Production of Space in Modern Capitalist Societies", Doctorate Thesis, ITU Architecture Faculty, 2003.

[11] Pallasmaa, J. (2011). An Architecture of Seven Senses, Toward a New Interior edited by Weinthal L., 40-49, Princeton Architectural Press, New York.

[12] http://m.milliyet.com.tr, 08/07/2017.

[13] Reiffenscheidt L.S. (2008). Die Basare Istanbuls, C. Branstatter Verlag, Wien

[14] Saglam N. (2015). "Interior Layers and a case Study in the Old Bedesten Cevahir", Master Thesis, ITU Graduate School of Science, Engineering and Technology. 